\title{
Optimized analysis of the clean depth waste heat utilization system in coal-fired power plant
}

\author{
Fengping $\mathrm{Pan}^{1, *}, \mathrm{JiaLuo}^{1}$, Yaqing Zhu ${ }^{1}$, Weijian $\mathrm{Huang}^{1}$, Lingling $\mathrm{Shi}^{1}, \mathrm{Kai} \mathrm{Su}^{1}$ \\ ${ }^{1}$ Electric Power Research Institute of Guangdong Grid Company, Guangzhou 510080, China
}

\begin{abstract}
In recent years, as a consequence of the rapidly increasing energy price and more and more stringent energy-saving and emission reduction policies, many effective measures have been taken by the majority of the coal-fired plants in China, including improving the power plant efficiency, reducing the unit standard coal consumption rate as well as pollutants emissions. Considering the characteristics of boiler flue gas and the operation process of pollutant removal devices, this study puts forward a kind of clean depth waste heat utilization system, which can recycle waste heat of the tail flue gas and improve pollutant removal efficiency. Taking a typical domestic 1000MW unit as example, we carry out the detailed thermodynamic calculation and an indepth exergy analysis on the system to evaluate the feasibility and the energy saving effect of this system. Results show that the proposed system can not only improve the pollutant removal efficiency significantly but also can bring a very high economic value and environmental benefits which will provide design ideas and theory analysis to the power plant design and transformation. And the energy saving effect of the system is outstanding.
\end{abstract}

\section{Introduction}

In China, the flue gas temperature of coal-fired power plants is generally designed in the range between $120{ }^{\circ} \mathrm{C}$ and $140{ }^{\circ} \mathrm{C}$. During the actual operation, the exhaust gas temperature is typically slightly higher. Therefore, the flue gas of utility boiler contains abundant waste heat resource. Using waste heat of boiler exhaust effectively is important in improving unit efficiency and reducing the coal consumption. In conventional research and application of waste heat utilization, low temperature economizer technology is one of the most widely used methods, a number of domestic units have carried out research in this field, and have realized practical application of this technology. Changchun second thermal power plant and Longkou power plant have made some system transformation in the utilization of low temperature economizer $[2,3]$. The Shanghai Waigaoqiao NO. 3 power plant $(2 \times 1000 \mathrm{MA})$ adopts "generalized heat recovery system" and makes that the low temperature economizer can heat feedwater both in parallel operation and series operation [4]. In Germany Cologne, the 1000 MW lignite generating units in Niederaussem use the bypass flue system to fully reduce exhaust gas temperature, and the energy saving effect is remarkable $[5,6]$. In theory research, Professor Lin Wanchao proposed earlier the use of equivalent enthalpy drop method to analyze the thermal economy of the low temperature economizer and its system in China [7]. In the aspect of optimal operation of the low temperature economizer of coal-fired power plants, professor Huang Xinyuan at al. [8,9] had carried on thorough analysis and researches. Three configuration schemes of low temperature economizer and theirs technical and economic performance were analyzed by Wang Yan , namely set before the dust collector ,after the induced draft fan and arranged around the dust collector in two stages [10].

Many Domestic and international scholars had carried out indepth study of the utilization of boiler waste heat, but most of these studies were just focused on the aspect of equipment modification and improving the economic benefit of the unit [11-13], and the waste heat utilization and pollutant removal were not considered. In order to fully realize the purpose of energy conservation and emissions reduction, the operation optimization of denitration equipment should be payed attention to at the same time in the realization of energy-saving reform of the unit.

In view of this, to improve the unit economy and control of pollutant emissions, this paper creatively puts forward the coal-fired power plant clean depth waste heat utilization system. In the domestic typical $1000 \mathrm{mw}$ ultra supercritical unit as a reference, we carry on the detailed thermodynamic analysis, the exergy analysis and the energy saving mechanism analysis. And then we analyze the energy saving efficiency and pollutant removal efficiency of the new system from the perspective of the first law and second law of thermodynamics. Finally we verify the effect of the new system for energy conservation and emissions reduction.

\section{The clean depth waste heat utilization system in coal-fired power plant}

\subsection{Operation status of power plants}

China's power generation industry which now has reached the international advanced level is heavily dependent on thermal power units, of which the majority are equiped with units of $600 \mathrm{mw}$ and above. But compared to hydropower, nuclear power, wind power and other new energy power generation units, thermal power units will cause many outstanding issues such as high energy consumption, serious pollution and so on. Besides, the exhaust temperature of the main thermal power units are still very high, exhaust gas loss is the main loss in thermal power stations. Taking appropriate means to reduce the heat loss of exhaust gas can effectively reduce the coal consumption rate of unit. The operating temperature of the denitration device is different from the optimal operating temperature area of the SCR, and if the 
operating temperature of SCR is properly adjusted, unit denitration efficiency will be improved. Thus there are great potential of modification and optimization in energy conservation and emissions reduction in thermal power plants.

\subsection{Proposal of the clean depth waste heat utilization system in coal-fired power plant}

In the face of the problem of energy conservation and emissions reduction of thermal power unit, this paper proposes the clean depth waste heat utilization system , characterized by the classification arrangement of economizer and air preheater in coal-fired power plant . Figure 1 shows the basic process of the system.

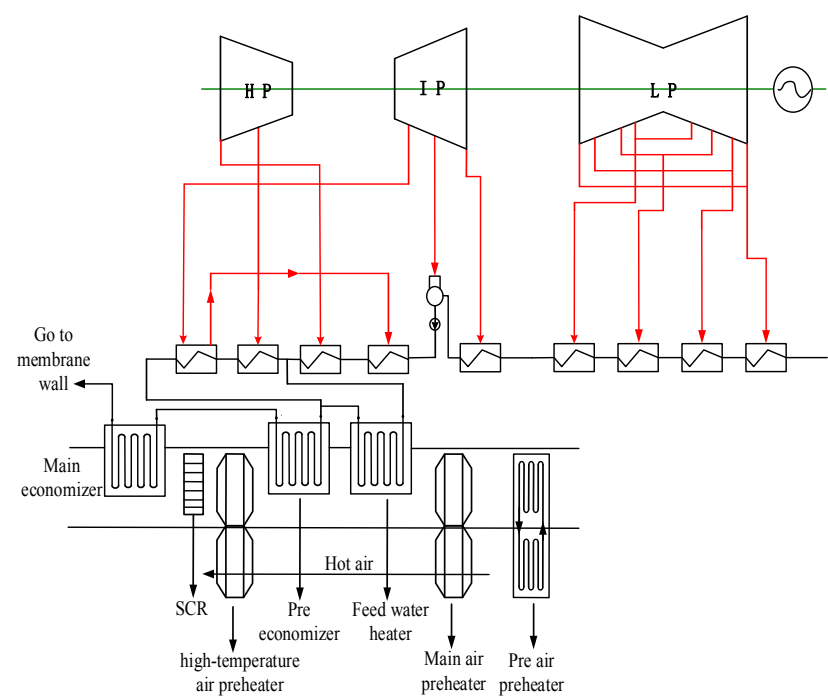

Figure 1. The clean depth waste heat utilization system

As shown in Figure 1, economizer is divided into the pre economizer and the main economizer in the system. SCR denitration equipment and high-temperature air preheater are installed between the two parts of the economizer, feed water heater is installed after the pre economizer and before the main air preheater. In order to improve the unit output, regenerative extraction steam is saved by using high temperature flue gas to heat the feed water of regenerative system. As a result of the arrangement of the feed water heater in the boiler flue, the heat absorption of air preheater is reduced, the outlet gas temperature cannot meet the requirement of the air temperature of furnace. Pre air preheater is installed in the boiler flue after the main air preheater, which can make up for the reduction of heat absorption of the pre air preheater and the main air preheater. In this design, the heat absorption of the main economizer is reduced, which causes the temperature increase of the outlet gas. And thus, the operation temperature of SCR device is increased, which improves the denitration efficiency. While the main air preheater inlet air temperature increases, the heat transfer temperature difference is reduced which lead to the reduction of exergy loss.

\section{System thermodynamic calculation and analysis of energy savings}

\subsection{Introduction of case unit}

Taking a domestic $1000 \mathrm{mw}$ ultra-supercritical coalfired power generating unit as example, this study carried out the thermal calculation of the clean depth waste heat utilization system in coal-fired power plant in detail. The calculation is based on qualities of design coal $\left(\mathrm{C}_{\mathrm{ar}}, \mathrm{H}_{\mathrm{ar}}\right.$, $\mathrm{O}_{\mathrm{ar}}, \mathrm{N}_{\mathrm{ar}}, \mathrm{S}_{\mathrm{ar}}, \mathrm{M}_{\mathrm{ar}}$ correspond to $57.33 \%, 3.26 \%, 9.43 \%$, $0.61 \%, 0.63 \%, 18.5 \%$ respectively). Major thermal parameters of the regenerative system of steam turbine and the boiler are showed in Table 1 and Table 2 respectively. And the Figure 2 shows the thermodynamic system diagram of case unit.

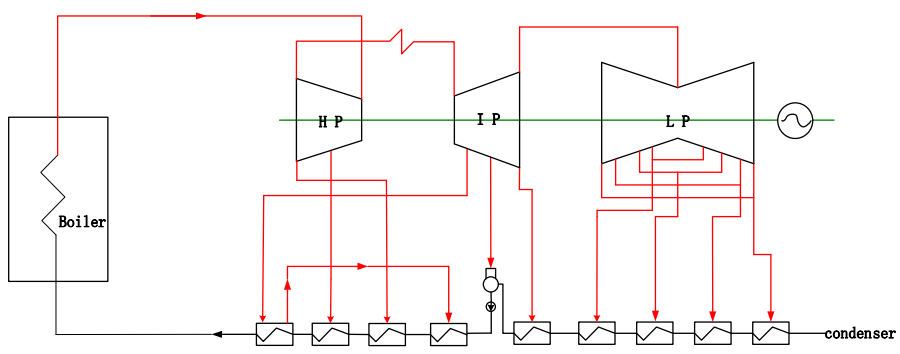

Figure 2. Thermodynamic system diagram of case unit

\subsection{System design principles}

Integrated application of the new system in engineering should follow the following two principles: 1 . In order to satisfy the feasibility of the heat exchanger in engineering, it is necessary to ensure the heat transfer temperature difference of heat exchangers is more than $20^{\circ} \mathrm{C}$. Since the pre air preheater adopts the water-coal type heat exchanger, the heat transfer temperature difference should be ensured more than $60^{\circ} \mathrm{C}$. 2. In order to avoid the occurrence of low-temperature corrosion of material, the pre air preheater outlet gas temperature should be set to $100^{\circ} \mathrm{C}$.

Table 1. Major thermal parameters of the regenerative system of steam turbine

\begin{tabular}{|c|c|c|c|c|c|c|c|c|}
\hline Parameters & $\begin{array}{c}\text { Inlet water } \\
\text { temperature/ } \\
{ }^{\circ} \mathrm{C}\end{array}$ & $\begin{array}{c}\text { Inlet } \\
\text { pressu } \\
\mathrm{re} \\
\mathrm{Mpa}\end{array}$ & $\begin{array}{c}\text { outlet } \\
\text { water } \\
\text { temper } \\
\text { ature } \\
/{ }^{\circ} \mathrm{C}\end{array}$ & $\begin{array}{c}\text { outlet } \\
\text { pressure } \\
/ \mathrm{Mpa}\end{array}$ & $\begin{array}{c}\text { Bled- } \\
\text { steam } \\
\text { tempera } \\
\text { ture } /{ }^{\circ} \mathrm{C}\end{array}$ & $\begin{array}{c}\text { Bled- } \\
\text { steam } \\
\text { pressure } \\
/ \mathrm{Mpa}\end{array}$ & $\begin{array}{c}\text { Regenerat } \\
\text { or mass } \\
\text { flow } /\left(\mathrm{kg} \cdot \mathrm{s}^{-}\right. \\
1\end{array}$ & $\begin{array}{c}\text { Drain } \\
\text { water } \\
\text { temperatur } \\
\mathrm{e} /{ }^{\circ} \mathrm{C}\end{array}$ \\
\hline Condenser & 295.4 & 32.45 & 299.3 & 32.20 & 484.7 & 2.29 & 785.84 & 303.4 \\
\hline 1\#regenerator & 273.7 & 32.54 & 295.4 & 32.45 & 406.0 & 8.09 & 758.84 & 279.3 \\
\hline 2\#regenerator & 216.3 & 32.63 & 273.7 & 32.54 & 359.3 & 5.78 & 758.84 & 221.9 \\
\hline 3\#regenerator & 186.4 & 32.72 & 216.3 & 32.63 & 303.4 & 2.23 & 758.84 & 192.0 \\
\hline
\end{tabular}


Table 2. The main thermodynamic parameters of the boiler side

\begin{tabular}{|c|c|}
\hline items & Parameters \\
\hline Economizer inlet water temperature $/{ }^{\circ} \mathrm{C}$ & 299.3 \\
\hline Economizer outlet water temperature $/{ }^{\circ} \mathrm{C}$ & 331.8 \\
\hline Economizer inlet flue gas temperature $/{ }^{\circ} \mathrm{C}$ & 469.5 \\
\hline Economizer outlet flue gas temperature $/{ }^{\circ} \mathrm{C}$ & 350.0 \\
\hline Air preheater inlet air temperature $/{ }^{\circ} \mathrm{C}$ & 26.2 \\
\hline Air preheater outlet air temperature $/{ }^{\circ} \mathrm{C}$ & 320.0 \\
\hline Air preheater inlet flue gas temperature $/{ }^{\circ} \mathrm{C}$ & 350.0 \\
\hline Air preheater outlet flue gas temperature $/{ }^{\circ} \mathrm{C}$ & 121.0 \\
\hline Flue flow rate $/\left(\mathrm{t} \cdot \mathrm{h}^{-1}\right)$ & 366.4 \\
\hline Boiler efficiency $/ \%$ & 94.59 \\
\hline
\end{tabular}

Taking into account the above two principles and the optimum reaction temperature zone of SCR denitration device, the system is designed as shown in Figure 1 to improve the unit economic performance as much as possible: (1) The Low temperature gas-water heat exchanger, out-set steam cooler and NO.1 high pressure heater are set in parallel. (2) Economizer is divided into the main economizer and pre-economizer, and the main economizer assumes the main heat transfer. (3) Air preheater system is divided into three stages, namely the high temperature air preheater, the main air preheater and pre-air preheater, among which the main air preheater assumes the main heat transfer.

\subsection{The main heat exchanger thermodynamic calculation}

In view of the system design principles in the section 3.2, combined with the reasonable design and thermodynamic calculation of the main heat exchanger in the clean depth waste heat utilization system, thermodynamic parameters of the heat exchanger can be obtained, summarized in Table 3 .

As can been seen from Table 3, each heat exchanger temperature difference of the new system are maintained at $20{ }^{\circ} \mathrm{C}$ and above, and the pre air preheater heat transfer temperature difference has reached $70{ }^{\circ} \mathrm{C}$, they all meet the principles in engineering feasibility of the system . In addition, the denitration temperature of new system namely the main economizer outlet flue gas temperature has reached $370{ }^{\circ} \mathrm{C}, 20{ }^{\circ} \mathrm{C}$ higher than that of the original system.

Table 3. Thermodynamic parameters of the system integration

\begin{tabular}{|c|c|c|c|c|c|c|}
\hline Items & $\begin{array}{c}\text { high- } \\
\text { temperature } \\
\text { economizer }\end{array}$ & $\begin{array}{c}\text { high- } \\
\text { temperature } \\
\text { air preheater }\end{array}$ & $\begin{array}{c}\text { Pre } \\
\text { economizer }\end{array}$ & $\begin{array}{c}\text { Feed water } \\
\text { heater }\end{array}$ & $\begin{array}{c}\text { Main air } \\
\text { preheater }\end{array}$ & $\begin{array}{c}\text { Pre air } \\
\text { preheater }\end{array}$ \\
\hline $\begin{array}{c}\text { inlet flue gas temperature } \\
/{ }^{\circ} \mathrm{C}\end{array}$ & 469.5 & 370.0 & 338.5 & 317.0 & 299.6 & 121.0 \\
\hline $\begin{array}{c}\text { outlet flue gas } \\
\text { temperature } /{ }^{\circ} \mathrm{C}\end{array}$ & 370.0 & 338.5 & 317.0 & 299.6 & 121.0 & 100.0 \\
\hline $\begin{array}{c}\text { inlet air/water temperature } \\
/{ }^{\circ} \mathrm{C}\end{array}$ & 305.2 & 280.0 & 299.3 & 273.7 & 54.0 & 26.2 \\
\hline $\begin{array}{c}\text { outlet air/water } \\
\text { temperature } /{ }^{\circ} \mathrm{C}\end{array}$ & 331.8 & 320.0 & 305.2 & 299.3 & 280.0 & 54.0 \\
\hline $\begin{array}{c}\text { (heat transfer) } \\
\text { temperature difference } /{ }^{\circ} \mathrm{C}\end{array}$ & 96.7 & 54.1 & 24.7 & 21.6 & 38.6 & 70.3 \\
\hline Heat transfer rate/(MW) & 108.19 & 33.08 & 23.34 & 18.88 & 187.38 & 23.10 \\
\hline
\end{tabular}

Table 4. The economy calculation results of the system

\subsection{System energy saving effect}

In order to avoid the occurrence of low-temperature corrosion of material, the pre air preheater outlet gas temperature should be set to $100^{\circ} \mathrm{C}$. In view of the system design principles in the section 3.2 , combined with the overall thermodynamic calculation of the clean depth waste heat utilization system, energy saving effect of the system can be obtained, summarized in Table 4, where the number of annual operating hours takes $5000 \mathrm{~h}$.

Table 4 data displays that the clean depth waste heat utilization system can reduce coal consumption by $3.69 \mathrm{~g}$ $/ \mathrm{kWh}$, annual savings of standard coal is more than $19,000 \mathrm{t}$, which means the energy-saving effect is remarkable.

\begin{tabular}{|c|c|c|c|}
\hline Items & Unit & $\begin{array}{c}\text { Conventiona } \\
\text { 1 system }\end{array}$ & $\begin{array}{c}\text { Proposed } \\
\text { system }\end{array}$ \\
\hline Gross power output & $\mathrm{MW}$ & 1012.7 & 1029.4 \\
\hline $\begin{array}{c}\text { Gross additional power } \\
\text { output }\end{array}$ & $\mathrm{MW}$ & - & 16.7 \\
\hline $\begin{array}{c}\text { Coal consumption * } \\
\mathrm{g} / \mathrm{kW} \\
\mathrm{h}\end{array}$ & 261.98 & 258.28 \\
\hline $\begin{array}{c}\text { Decrease in coal } \\
\text { consumption * }\end{array}$ & $\begin{array}{c}\mathrm{g} / \mathrm{kW} \\
\mathrm{h}\end{array}$ & - & 3.69 \\
\hline $\begin{array}{c}\text { Saving of standard coal } \\
\text { yearly }\end{array}$ & $\begin{array}{c}\mathrm{t} / \mathrm{yea} \\
\mathrm{r}\end{array}$ & - & 19234 \\
\hline
\end{tabular}

*In this study, all coal consumption data refers to the standard coal consumption. 


\section{System exergy analysis}

\subsection{Energy saving mechanism analysis of system heat transfer process}

Based on the first law of thermodynamics, the detailed thermodynamic calculation is carried out in sections 2.3 and 2.4. In order to reveal essentially the flue gas heat conversion efficiency of the new system, this section conducts a detailed contrast analysis of exergy calculation of the part of main heat transfer in the new system and the original system. The whole calculation has based on the second law of thermodynamics, exploring the essence of energy saving mechanism in the new system.

According to the literature [14], the irreversible heat transfer process exergy loss of the heat exchanger can be calculated by the following equation:

$$
\delta E_{X, L}=T_{0} \delta Q\left(\frac{1}{T_{L}}-\frac{1}{T_{H}}\right)=T_{0} \delta Q \frac{T_{H}-T_{L}}{T_{H} T_{L}}
$$

Where: TH, TL denote the temperature of the cold, hot object, respectively.

It can be seen from the above equation that heat transfer process exergy loss of heat exchangers is proportional to the temperature difference between the hot and cold objects (TH-TL) , and inversely proportional to the product of the absolute temperature of the hot and cold objects (TH*TL). Thus, the greater the temperature difference, the greater exergy loss of the heat transfer process is. When the heat transfer amount of the heat exchanger is constant, the heat transfer temperature difference is inversely proportional to the heat transfer area, Therefore, restricted by heat transfer area and feasibility in project, temperature difference can not be too small, it still needs to meet certain requirements. Figure 3 and Figure 4 show the T-Q curve of case unit of the original system and the new system, respectively. The abscissa is the heat load (MW), showing the heat transfer amount between hot and cold fluids. The ordinate is the temperature of hot and cold fluids, slope of the curve indicates the reciprocal of fluid heat capacity.

As the two T - Q curves describe: (1) Compared to the original system, the new system reduces the design temperature of the flue gas from $121{ }^{\circ} \mathrm{C}$ to $100^{\circ} \mathrm{C}$. The cold air has been heated in the pre air preheater, which improves the air preheater inlet air temperature, reduces the heat transfer temperature difference of air preheater, and then reduces the exergy loss of the system. (2) More ideal energy-saving effect can be achieved because the pre-set air preheater installed in the new system can save high-grade steam extraction by taking advantage of the high grade flue gas waste heat to heat feedwater of regenerative system. (3) The heat transfer temperature increase of high-temperature air preheater helps reduce heat exchange exergy loss.

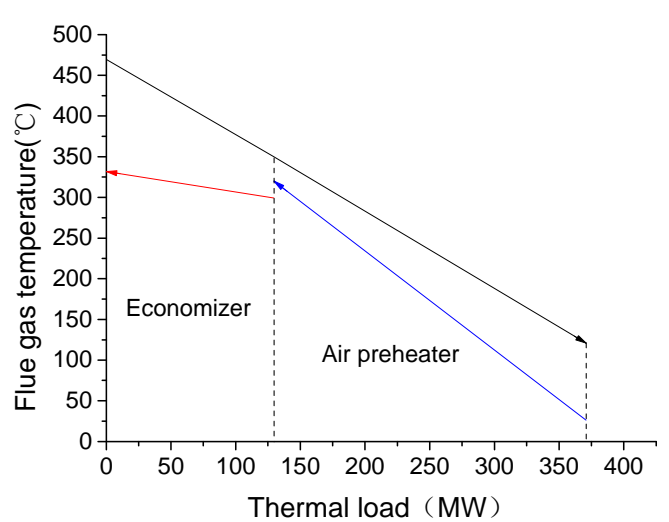

Figure 3. The original system T-Q diagram of case unit

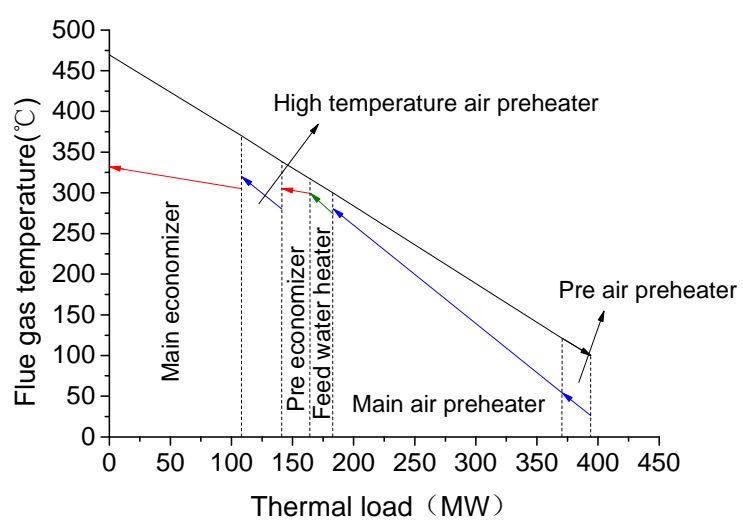

Figure 4. The new system T-Q diagram of case unit

\subsection{Each calculation units of exergy analysis}

In order to facilitate the detailed calculation of the original and new systems of the case unit, in this study, the original system is divided into four calculation units, namely the coal boiler system in front of economizer(excluding the economizer), the economizer, the air preheater, steam turbine and regenerative system. Also the new system is divided into eight calculation units, namely the coal boiler system in front of economizer (excluding the economizer), the main economizer, the pre-set economizer, the main air preheater, the pre-set air preheater, the high-temperature air preheater, the feed water heat exchanger, steam turbine and regenerative system.

Exergy loss of each calculation units can be obtained through the corresponding exergy balance equations in general, usually can be calculated by using the following equation:

$$
\Sigma E_{\text {in }}+\Sigma E_{Q, \text { in }}+\Sigma W_{\text {in }}=\Sigma E_{\text {out }}+\Sigma E_{\text {Q,out }}+\Sigma W_{\text {out }}+\Sigma I_{r}
$$

And exergy efficiency of each calculation units and the whole system can be calculated by the following equation:

$$
\eta=\frac{\Sigma W_{\text {out }}-\Sigma W_{\text {in }}}{\left(\Sigma E_{\text {in }}+\Sigma E_{Q, \text { in }}\right)-\left(\Sigma E_{\text {out }}+\Sigma E_{Q, \text { out }}\right)}
$$


Table 5. The calculation results of each unit exergy loss

\begin{tabular}{|c|c|c|c|c|}
\hline \multirow{2}{*}{ Items } & \multicolumn{2}{|c|}{ Conventional system } & \multicolumn{2}{c|}{ Proposed system } \\
\cline { 2 - 5 } & $\begin{array}{c}\text { exergy (exergy } \\
\text { loss } / \mathrm{MW}\end{array}$ & $\begin{array}{c}\text { Exergy } \\
\text { efficiency } / \%\end{array}$ & $\begin{array}{c}\text { exergy (exergy loss) } \\
\text { /MW }\end{array}$ & $\begin{array}{c}\text { Exergy } \\
\text { efficiency } / \%\end{array}$ \\
\hline Fuel exergy & 2215.81 & - & 2220.81 & - \\
\hline Power output & 1012.70 & - & 1029.36 & 51.67 \\
\hline $\begin{array}{c}\text { coal boiler system in front of } \\
\text { economizer(excluding the } \\
\text { economizer) }\end{array}$ & 1021.09 & 51.66 & 1023.40 & 88.18 \\
\hline $\begin{array}{c}\text { Turbine and the regenerative } \\
\text { system }\end{array}$ & 143.15 & 87.62 & 138.00 & 90.95 \\
\hline Main economizer & 5.18 & 92.62 & 5.35 & 91.28 \\
\hline high-temperature air preheater & - & - & 1.49 & 97.60 \\
\hline Pre economizer & - & - & 0.27 & 98.77 \\
\hline Feed water heater & - & - & 0.11 & 81.99 \\
\hline Main air preheater & 21.46 & 77.22 & 12.58 & 22.72 \\
\hline Pre air preheater & - & - & 3.79 & - \\
\hline Exhaust gas & 13.35 & - & 8.45 & 92.03 \\
\hline Economizer summary & 5.18 & 92.62 & 5.63 & 46.35 \\
\hline air preheater summary & 21.46 & 77.22 & 19.86 & 1193.46 \\
\hline overall unit & 1204.22 & 45.70 & & -55 \\
\hline
\end{tabular}

\subsection{Exergy analysis}

Exergy efficiency of each calculation units and the whole system which is calculated according to the method specified in section 3.2 are summarized in Table 5 .

As shown in Table 5, exergy efficiency of the new system is significantly superior to the original system. Exergy loss of the steam turbine and regenerative system, the air preheater system have all decreased.And thus the exergy efficiency increases. Due to part of extraction steam of No. 1 high pressure heater has been saved by the exist of feedwater heat exchanger, there is a certain increase of both the boiler input and output exergy value (considering the fuel quantity increase due to reheat heat absorption increases). So exergy efficiency of boiler system before the economizer basically remain unchanged. According to the equation (1), due to the gas temperature and air temperature of high-temperature air preheater have relatively increased, the unit exergy loss is obviously decreased and exergy efficiency is obviously increased. Meanwhile, the main air preheater inlet air temperature is increased, and that the temperature difference decreases, the main air preheater unit exergy efficiency is higher compared to that of original system. But in pre air preheater, the low flue gas temperature and air temperature lead to a low exergy efficiency. Overall, the exergy efficiency of air preheater of new system has upgraded by $3.33 \%$ compared with original system. Since some heat is brought into the calculation unit system by the feedwater heater, the extraction steam volume decreases, thereby reducing the irreversible loss and increasing steam turbine and heat recovery systems exergy efficiency slightly. The temperature difference increases with the main economizer outlet flue gas temperature in proposed system increases, so that the exergy efficiency becomes lower. And so the pre economizer exergy efficiency is lower because of the reduction of flue gas temperature. The added feedwater heater brings about energy loss of $0.11 \mathrm{MW}$.

In general, in the case of the fuel exergy input system increases by $5 \mathrm{MW}$, the exergy loss of new system is $1193.46 \mathrm{MW}$ in total which is $10.76 \mathrm{MW}$ lower than the original system. Compared with the original system, the new system exergy efficiency increases significantly from $45.70 \%$ to $46.35 \%$.

\section{Analysis of the influence on the system denitration efficiency}

Facing the growing pressure for environmental protection, most of the power plants have been equipped with denitration device. Currently the SCR flue gas denitration technology is widely used in power plants, mainly using $\mathrm{V}_{2} \mathrm{O}_{5}-\mathrm{WO}_{3} / \mathrm{TiO}_{2}$ catalyst. The denitration efficiency can be influenced by various factors, among which the working temperature of catalyst has a significant impact. The optimal working temperature range of the catalyst is $340 \sim 380{ }^{\circ} \mathrm{C}$. When the SCR denitration device inlet temperature is under $360 \sim 380{ }^{\circ} \mathrm{C}$, the SCR denitration efficiency is increased and the ammonia escape rate is reduced with the increase of temperature, and then the blockage problem of air preheater has been relieved [15]. Inlet gas temperature of SCR denitrification device at different loads are quite different. When the unit is running at low load, denitration device works in low temperature that seriously deviates from the optimum temperature, which would result in denitration efficiency reduction. Improving the working temperature of denitration device can effectively improve device denitration efficiency, and achieve the goal of reducing pollutant emissions. 
Table 6. Comparison of SCR denitration efficiency of the two systems

\begin{tabular}{|c|c|c|c|c|}
\hline Items & $100 \%$ & $90 \%$ & $75 \%$ & $50 \%$ \\
\hline $\begin{array}{c}\text { The conventional system } \\
\text { denitration temperature } /{ }^{\circ} \mathrm{C}\end{array}$ & 353 & 346 & 333 & 314 \\
\hline $\begin{array}{c}\text { The proposed system } \\
\text { denitration temperature } /{ }^{\circ} \mathrm{C}\end{array}$ & 370.0 & 363.3 & 350.8 & 332.1 \\
\hline $\begin{array}{c}\text { Increase of denitration } \\
\text { temperature } /{ }^{\circ} \mathrm{C}\end{array}$ & 17.0 & 17.3 & 17.6 & 18.1 \\
\hline $\begin{array}{c}\text { The conventional system } \\
\text { denitration efficiency } / \%\end{array}$ & 86.2 & 85.2 & 83.2 & 77.1 \\
\hline $\begin{array}{c}\text { The proposed system } \\
\text { denitration efficiency } / \%\end{array}$ & 88.6 & 87.7 & 85.9 & 83.1 \\
\hline $\begin{array}{c}\text { Increase of denitration } \\
\text { efficiency } / \%\end{array}$ & 2.4 & 2.5 & 2.7 & 6.0 \\
\hline
\end{tabular}

The clean depth waste heat utilization system adoptes the partition design of economizer, which can improve SCR device inlet flue gas temperature by reducing the heat absorption of the high temperature section of economizer, reaching the purpose of improving the denitration efficiency. This study obtains inlet flue gas temperature of denitration device under various load by conducting a detailed thermodynamic calculation of four different load rates of the case unit, namely $100 \%$, $90 \%, 75 \%$ and $50 \%$. And also, based on the relationship between denitrification efficiency and temperature which has been given in the literature, this study has compared the denitration efficiency of the new system and the original system. Summary data are presented in table 6 .

It can clearly be seen from Table 6 that the operating temperature of the new system SCR denitrification device has improved at various load. SCR device inlet flue gas temperature has increased by $17.0^{\circ} \mathrm{C}$, $17.3{ }^{\circ} \mathrm{C}, 17.6{ }^{\circ} \mathrm{C}$ and $17.3{ }^{\circ} \mathrm{C}$ when the New system under $100 \%, \quad 90 \%, \quad 75 \%$ and $50 \%$ load, respectively, corresponding to the denitration efficiency increment of $2.4 \%, 2.5 \%, 2.7 \%$ and $6.0 \%$. The operating temperature of the new system has greatly increased compared with that of the original system. And the denitrification efficiency at low load has a great increase with a small temperature difference change of denitrification device under various load because the denitrification efficiency change rates are quite different in different temperature regions. Overall, the new system can effectively improve the denitrification effect under various load, especially when under low load.

\section{Energy saving analysis of the clean optimization system}

(1) Air preheater and economizer are classified to realize the multi-grade using of energy.

Comparison of Figure 3 and Figure 4 shows that the clean optimization system has adopted the classification of the air preheater and the economizer. Air heating process is divided into three stages. In the heating process, low-temperature flue gas displace the high-grade heat to heat water in the pre-air preheater. And the heat transfer temperature difference between air and flue gas is more reasonable, thus heat transfer temperature difference and exergy loss are reduced, the multi-grade using of energy has been realized.

(2) High parameter extraction steam are saved to achieve substantial energy saving of unit.

As previously mentioned, the pre-air preheater improves the inlet air temperature of the primary air preheater by using the low temperature flue gas to heat the cold air. And the high grade flue gas which has been displaced is used for heating the regenerative system feedwater and the inlet flue gas temperature of the feed water heater reaches $317^{\circ} \mathrm{C}$. Compared to the low temperature economizer system, the grade of the steam turbine extraction which has been replaced and the energy saving effect are obviously enhanced.

(3) A reasonable heat transfer temperature difference has been chosen to satisfy the engineering requirements.

The classification of the air preheater and the economizer makes that air and water can be heated by several times and then the temperature difference of heat exchange equipment are reduced accompanied with the decrease of exergy loss and the increase of exergy efficiency. Meanwhile, in order to ensure the heat transfer performance of the heat exchanger and meet the engineering requirements, the design of the proposed system has limited the reduction of the heat transfer temperature difference.

(4) Power plant operation analysis in cold winter circumstances.

In this design, the air is heated in the pre-set air preheater before flowing into the main air preheater. Cold weather results in the decrease of pre-set air preheater inlet air temperature, which makes the outlet temperature of each air preheater stage can't all meet the design requirements, and then the boiler inlet air temperature that can directly influence the boiler's ignition and the boiler efficiency is reduced. Therefore, in order to stabilize the boiler ignition and to ensure the boiler efficiency, the system still retains an air heater, uses low grade extraction steam of turbine preheating the cool air, guarantees that boiler inlet wind temperature has met the requirements. By this way, the energy saving effect is relatively stable.

\section{Conclusion}

Based on the analysis of the conventional system, a novel system called clean depth waste heat utilization system of coal-fired power station is proposed in this 
study. And the design principles and working process of the system are introduced in detail. From the perspective of the first law and second law of thermodynamics, this study has carried out the detailed thermodynamic calculation and exergy analysis of each part of the system. In addition, we analyze how the proposed system influence on the denitrification system. Some meaningful conclusions gained from this paper, mainly including the followings:

(1) The new system presents an obvious advantages in energy saving effect for the conventional system. Taking the case unit as an example, the power generation coal consumption reduction of $3.69 \mathrm{~g} / \mathrm{kWh}$ brings about more than 19000 tons of standard coal savings each year.

(2) Exergy analysis results shows that, the exergy loss of the air preheater, the steam turbine and heat recovery systems in new system are reduced by $1.6 \mathrm{MW}$ and $5.1 \mathrm{MW}$ respectively compared with the conventional system,. And the total system exergy loss is reduced by $10.8 \mathrm{MW}$ which makes the exergy efficiency increased by $0.65 \%$. All data indicates that the proposed system can achieve more efficient and reasonable utilization of heat.

(3) From the perspective of pollutant removal performance, the new system can improve the SCR denitrification efficiency under different loads, and the effect is more pronounced when under low load, the effect of energy saving and emission reduction is obvious.

\section{References}

[1] Tian H, Wang Y, Cheng K, et al., Journal of the Air \& Waste Management Association, 62, 576586(2012)

[2] Jianling Deng, Shengwei Huang, Gang $\mathrm{Xu}$, et al., East China Electric Power, 41, 200-204(2013)

[3] Xinyuan Huang, Boiler Technology, 3, 22- 25(1998)

[4] Hezhong Liu, Zhengquan Lian Electric Power Survey \& Design, 4, 32-38(2010)

[5] Yongjian Ye, Songlin Shen, Electric Power Construction, 32, 54-58(2011)

[6] RUSENBERG D, HEITMULlER R J, SCHEFFKNECHT G, et al, Power-Gen Europe Conference, (2002)

[7] Wanchao Lin, Shiwen Sun, Electric Power Technology, 9, 17-20(1991)

[8] Xinyuan Huang, Liping Wang, Power System Engineering, 15, 20-25(1999)

[9] Xinyuan Huang, Yaming Ping , Fengzhong Swn, Journal of Hydrodynamics, 18, 526-531(2003)

[10] Yan Wang, Applied Energy Technology, 7, 2834(2013)

[11] Espatolero S, Cortés C, Romeo L M, Applied Energy, 87, 1651-1660(2010)

[12] Wang C, He B, Yan L, et al, Energy, 65, 80-90(2014)

[13]Lin Chen, Yingying Sun, Xiaoze Du, et al. ,Proceedings of the CSEE, 34, 2778-2783(2014)

[14]Qinsheng $\mathrm{Fu}, \mathrm{Xi}$ 'an: Xi 'an jiaotong university press, 137-140(2005)

[15]Jianguo Yang, Li'an Fan, Hong Zhao, et al. ,Proceedings of the CSEE, 34, 2244-2250(2014) 